medRxiv preprint doi: https://doi.org/10.1101/2021.07.21.21260905; this version posted July 22, 2021. The copyright holder for this preprint (which was not certified by peer review) is the author/funder, who has granted medRxiv a license to display the preprint in perpetuity. It is made available under a CC-BY-NC-ND 4.0 International license.

\title{
1 A Wastewater-based Epidemiology tool for COVID-19 Surveillance in Portugal
}

2 Sílvia Monteiro ${ }^{a,{ }^{*}}$, Daniela Rente ${ }^{a}$, Mónica V. Cunha ${ }^{b, c}$, Manuel Carmo Gomes ${ }^{d}$, Tiago

3 A. Marques ${ }^{\mathrm{e}, \mathrm{f}}$, Artur B. Lourenço $^{\mathrm{b}}$, Eugénia Cardosog $^{\mathrm{g}}$, Pedro Álvarog, Marco Silva ${ }^{\mathrm{h}}$,

4 Norberta Coelho ${ }^{h}$, João Vilaçai, Fátima Meireles', Nuno Brôcoj, Marta Carvalhoj,

$5 \quad$ Ricardo Santos ${ }^{a}$

6

7 a Laboratorio de Análises, Instituto Superior Técnico, Universidade de Lisboa, Lisbon,

8 Portugal

9 b Centre for Ecology, Evolution and Environmental Changes (cE3c), Faculdade de 10 Ciências, Universidade de Lisboa, 1749-016 Lisboa, Portugal.

11 c Biosystems \& Integrative Sciences Institute (BiolSI), Faculdade de Ciências,

12 Universidade de Lisboa, 1749-016 Lisboa, Portugal.

$13{ }^{d}$ Departamento de Biologia Vegetal, Faculdade de Ciências, Universidade de Lisboa,

14 1749-016 Lisboa, Portugal.

15 e Centre for Research into Ecological and Environmental Modelling, The Observatory,

16 University of St Andrews, St Andrews, KY16 9LZ, Scotland.

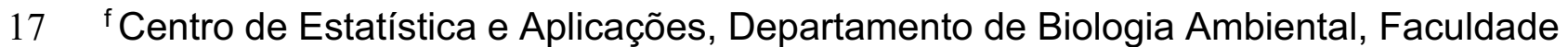
de Ciências, Universidade de Lisboa, 1749-016, Lisboa, Portugal.

19 Águas do Tejo Atlântico, Fábrica de Águas de Alcântara, Avenida de Ceuta, 130020254 Lisboa, Portugal.

21 h Águas do Norte, Lugar de Gaído, 4755-045 Barcelos, Portugal

i SIMDOURO, ETAR de Gaia Litoral, 4400-356 Canidelo, Portugal 
medRxiv preprint doi: https://doi.org/10.1101/2021.07.21.21260905; this version posted July 22, 2021. The copyright holder for this preprint (which was not certified by peer review) is the author/funder, who has granted medRxiv a license to display the preprint in perpetuity. It is made available under a CC-BY-NC-ND 4.0 International license .

23 j AdP VALOR, Serviços Ambientais, S.A., Rua Visconde de Seabra, 3, 1700-421

24 Lisboa, Portugal 
medRxiv preprint doi: https://doi.org/10.1101/2021.07.21.21260905; this version posted July 22, 2021. The copyright holder for this preprint (which was not certified by peer review) is the author/funder, who has granted medRxiv a license to display the preprint in perpetuity.

\section{Abstract}

Shedding of severe acute respiratory syndrome coronavirus 2 (SARS-CoV-2) RNA in the feces and urine of infected patients and subsequent presence in wastewater has produced interest on the use of this matrix for sentinel surveillance at a community level and as a complementary approach to syndromic surveillance. With this work, we set the foundations for wastewater-based epidemiology (WBE) in Portugal by monitoring the trends of SARS-CoV-2 RNA circulation in the community, on a nationwide perspective during different epidemiological phases of the pandemic. The Charité assays (E_Sarbecco, RdRP, and N_Sarbecco) were applied to monitor, over 32-weeks (April to December 2020), the dynamics of SARS-CoV-2 RNA at the inlet of five wastewater treatment plants (WWTP), which together serve more than two million people in Portugal. Raw wastewater from three COVID-19 reference hospitals was also analyzed during this period. In total, more than 600 samples were tested.

Sampling started late April 2020, during lockdown, and, for the first weeks, detection of SARS-CoV-2 RNA was sporadic, with concentrations varying from $10^{3}$ to $10^{5}$ genome copies per liter (GC/L). Prevalence of SARS-CoV-2 RNA increased steeply by the end of May into late June, mainly in Lisboa e Vale do Tejo region (LVT), during the reopening phase. After the summer, with the reopening of schools in midSeptember and return to partial face-to-face work, a pronounced increase of SARSCoV-2 RNA in wastewater was detected. In the LVT area, SARS-CoV-2 RNA load agreed with reported trends in hotspots of infection. Synchrony between trends of SARS-CoV-2 RNA in raw wastewater and daily new COVID-19 cases highlights the value of WBE as a surveillance tool for this virus, particularly after the phasing out of the epidemiological curve and when hotspots of disease re-emerge in the population 
medRxiv preprint doi: https://doi.org/10.1101/2021.07.21.21260905; this version posted July 22,2021 . The copyright holder for this preprint

(which was not certified by peer review) is the author/funder, who has granted medRxiv a license to display the preprint in perpetuity.

It is made available under a CC-BY-NC-ND 4.0 International license .

49 which might be difficult to spot based solely on syndromic surveillance and contact

50 tracing.

51

52 Keywords:

53 SARS-CoV-2; wastewater-based epidemiology; COVID-19; hospital wastewater 54 
medRxiv preprint doi: https://doi.org/10.1101/2021.07.21.21260905; this version posted July 22, 2021. The copyright holder for this preprint (which was not certified by peer review) is the author/funder, who has granted medRxiv a license to display the preprint in perpetuity.

1. Introduction

Climate change, deforestation and population growth led to an increase in contact

between humans and wildlife, which may cause interspecies transmission of infectious agents. Such conditions possibly resulted in the occurrence of previous outbreaks including the severe acute respiratory syndrome (SARS; 2002-2004) and the Middle

60 East respiratory syndrome (MERS; 2012-present) outbreaks, all caused by coronavirus (CoV; SARS-CoV and MERS-CoV, respectively). Several authors that have addressed the environmental circulation of viruses had already highlighted the possible occurrence of a new pandemic caused by coronavirus (Wigginton and Ellenberg, 2015; Santos and Monteiro, 2013).

Coronavirus disease 2019 (COVID-19) is caused by the severe acute respiratory syndrome coronavirus 2 (SARS-CoV-2), an enveloped, single-stranded RNA virus with high infection rate. The first clinical cases in Portugal were reported on March 2, 2020, entering the exponential phase on March 14, 2020 (RTP, 2020). The Portuguese government closed schools on March 16, 2020, and declared the emergency state on March 19, 2020, with the country entering the first national lockdown until May 2, 2020. Reopening occurred in three stages throughout the month of May, with full reopening in June 2020 except for schools that remained closed throughout the month. In September, schools reopened, and partial face-to-face work returned, leading to a steep increase in the number of cases (DGS, 2020). As of December 2, 2020, 73,876 COVID-19 cases had been reported in Portugal, with 4,724 deaths and 229,018 recovered patients (DGS, 2020).

Although COVID-19 clinical tests have been developed in record time, the disease spread, and community infection burden often outpaced the capacity for clinical 
medRxiv preprint doi: https://doi.org/10.1101/2021.07.21.21260905; this version posted July 22, 2021. The copyright holder for this preprint (which was not certified by peer review) is the author/funder, who has granted medRxiv a license to display the preprint in perpetuity. It is made available under a CC-BY-NC-ND 4.0 International license .

and seriousness of clinical symptoms, and how this coincides with diseases known to circulate in the community (Mandi et al., 2020). Rapid approaches to determine the extent of virus spread in the population, ideally in near real-time, are thus needed to slow down transmission.

Wastewater-based epidemiology (WBE) has been applied since 2005 to trace pharmaceutical and illicit drug use in the community (Zuccato et al, 2005; Reddy, 2010; Singer et al., 2013; Choi et al., 2018). The usefulness and potential of wastewater as a surveillance system for pathogens has already been shown, namely under the global polio eradication initiative, the most successful example of environmental surveillance to date (Hovi et al., 2012; WHO, 2015; Koopmans et al., 2017).

Several advantages are associated with WBE; firstly, testing wastewater means testing thousands of potentially infected individuals at the same time, with the capacity to identify hotspots of infection prior to symptomatic surveillance. Secondly, WBE can highlight trends in virus shedding over time from symptomatic but also from asymptomatic, pre-symptomatic and post-symptomatic individuals.

SARS-CoV-2 although transmitted mainly via respiratory droplets (Meselson, 2020). has been detected in feces and urine of infected patients, regardless of disease severity or development of gastrointestinal illness (He et al., 2020; Pan et al., 2020; Wölfel et al., 2020; Young et al., 2020). Although there is little indication that virus shed in the stools of infected patients, and therefore circulating in wastewater, are infectious (Wölfel et al., 2020; Zang et al., 2020), the presence of SARS-CoV-2 RNA in raw wastewater provides valuable information regarding the emergence, prevalence, epidemiology and decrease of SARS-CoV-2 presence in the community, helping the early identification of hotspots of infection. 
medRxiv preprint doi: https://doi.org/10.1101/2021.07.21.21260905; this version posted July 22, 2021. The copyright holder for this preprint

(which was not certified by peer review) is the author/funder, who has granted medRxiv a license to display the preprint in perpetuity. It is made available under a CC-BY-NC-ND 4.0 International license.

105 To date, several authors reported the occurrence of SARS-CoV-2 RNA in wastewater

106 samples (Ahmed et al., 2020; Medema et al., 2020; Randazzo et al., 2020; Sherchan

107 et al., 2020) demonstrating the usefulness of WBE for SARS-CoV-2. Several iterations

108 of the application of WBE for SARS-CoV-2 are currently implemented in many

109 countries, such as the Netherlands, Scotland and Spain among others.

110 In this study, we report for the first time the results of SARS-CoV-2 RNA monitoring in

111 raw wastewater in Portugal, in a study covering about $20 \%$ of the Portuguese

112 population, corresponding to over two million people, over a 32-weeks period. More

113 than 600 samples were collected from five wastewater treatment plants (WWTP) and

114 three COVID-19 hospitals in two regions of the country, a north cluster (four

115 municipalities) and a south cluster in Lisboa e Vale do Tejo (LVT) (six municipalities)

116 To the best of our knowledge, this is the first study jointly evaluating the presence of

117 SARS-CoV-2 RNA in raw wastewater from WWTP and COVID-19 hospitals while

118 encompassing distinct epidemiological phases of the pandemic as well. 
medRxiv preprint doi: https://doi.org/10.1101/2021.07.21.21260905; this version posted July 22, 2021. The copyright holder for this preprint (which was not certified by peer review) is the author/funder, who has granted medRxiv a license to display the preprint in perpetuity.

2.1. Clinical surveillance data

121 Clinical surveillance data were obtained from the Reports from the Portuguese Health

122 Authority (DGS, 2020). Data from clinical surveillance for each municipality were

123 presented daily in the reports from the Health Authority, being provided on a weekly basis after July 2020.

2.2. Sampling sites and sample collection

126 Raw wastewater samples $(n=404)$ were collected between April 27, 2020, and

127 December 2, 2020, from five WWTP located in the North (Gaia Litoral (GA) and 128 Serzedelo II (SE)) and in LVT (Alcântara (AL), Beirolas (BE), and Guia (GU)) (Fig. S1)

129 of Portugal. Further information about these WWTP catchments is provided in Table

130 S1. Sampling took place for 102 days, covering 220 of calendar days in total.

131 Raw wastewater from three reference COVID-19 hospitals (Hospital Curry Cabral 132 (HCC), Lisbon; Hospital Sra. Oliveira (HSO), Guimarães (North); and Hospital Santos 133 Silva (HSS), Vila Gaia (North); $n=204$ ), in the catchment area of the WWTP, was also 134 sampled.

135 Twenty-four-hour composite samples were collected using automated samplers 136 (ISCO, US), except for HSO and HSS, where due to logistical problems only grab 137 samples were taken. Samples were transported refrigerated to the laboratory, within $1388 \mathrm{~h}$ of collection and processed immediately upon arrival to the laboratory.

\subsection{Processing of raw wastewater}

141 Upon arrival to the laboratory, 1-L of raw wastewater from WWTP and COVID-19

142 hospitals was concentrated using hollow-fiber filters Inuvai R180 (Inuvai, a division of 143 Fresenius Medical Care, Germany). Samples were eluted in $300 \mathrm{~mL}$ of $1 \mathrm{X}$ PBS 
medRxiv preprint doi: https://doi.org/10.1101/2021.07.21.21260905; this version posted July 22, 2021. The copyright holder for this preprint (which was not certified by peer review) is the author/funder, who has granted medRxiv a license to display the preprint in perpetuity. It is made available under a CC-BY-NC-ND 4.0 International license .

containing $0.01 \% \mathrm{NaPP}$ and 0.01 Tween $80 / 0.001 \%$ antifoam and precipitated overnight with $20 \%$ polyethylene-glycol (PEG) 8000 . Samples were then centrifuged at $10000 \mathrm{xg}$ for $30 \mathrm{~min}$ and resuspended in $5 \mathrm{~mL}$ 1X PBS, pH 7.4 (Blanco et al., 2019). Samples were kept at $(-80 \pm 10)^{\circ} \mathrm{C}$ until further processing.

2.4. Viral extraction, detection, and quantification

Viral RNA was extracted from $220 \mu \mathrm{L}$ concentrated samples using the QIAamp FAST DNA Stool Mini kit (QIAGEN, Germany), according to the manufacturer's instructions. The RNA was recovered in a final volume of $100 \mu \mathrm{L}$.

Primers and probes used in this study are presented in Table 1. The recovery efficiency for RNA extraction was performed using murine norovirus (MNV), which was added to the concentrates as an extraction control. MNV RNA was detected and quantified using the assay described by Baert et al., 2008. SARS-CoV-2 RNA was detected using the Charité assays: the E_Sarbecco, targeting the envelope protein gene, the RdRp that targets the RNA-dependent RNA polymerase gene and the N_Sarbecco, which targets the nucleoprotein (Corman et al., 2020).

One-step RT-qPCR assays (AgPath-ID ${ }^{\mathrm{TM}}$ One-Step RT-PCR, Thermo Scientific, USA) was used for the quantitative detection of SARS-CoV-2 and MNV. For the specific detection and quantification of viral RNA, $5 \mu \mathrm{L}$ of 4 -fold and 10 -fold dilutions of each viral RNA extract were also assayed in parallel with crude extracts; dilutions were meant to overcome amplification inhibition due to the complex nature of the samples. The final volume of reaction mixture was $25 \mu \mathrm{L}$, composed of $800 \mathrm{nM}$ of each primer, $200 \mathrm{nM}$ of probe and $5 \mu \mathrm{L}$ of extracted RNA. RT-qPCR reactions were carried out at $45{ }^{\circ} \mathrm{C}$ for $10 \mathrm{~min}, 95^{\circ} \mathrm{C}$ for $10 \mathrm{~min}$, followed by 45 cycles of amplification at 95 ${ }^{\circ} \mathrm{C}$ for $15 \mathrm{~s}$ and $58^{\circ} \mathrm{C}$ for $45 \mathrm{~s}$ for SARS-CoV-2 and $60^{\circ} \mathrm{C}$ for $45 \mathrm{~s}$ for MNV. RT-qPCR 
medRxiv preprint doi: https://doi.org/10.1101/2021.07.21.21260905; this version posted July 22, 2021. The copyright holder for this preprint (which was not certified by peer review) is the author/funder, who has granted medRxiv a license to display the preprint in perpetuity. It is made available under a CC-BY-NC-ND 4.0 International license.

169 was performed on an Applied Biosystems 7300 Real-Time PCR System (Applied

170 Biosystems, US). Reactions were considered positive only if the cycle threshold was

171 below 40 cycles (Medema et al., 2020; F. Wu et al, 2020). Quantification of

172 E_Sarbecco and RdRp assays was performed through calibration curves using 10-

173 fold dilutions of nCoV-ALL-Control plasmid (Eurofins Genomics, Germany), ranging

174 from 1.94 to $1.94 \times 10^{6}$ and 1.00 to $1.00 \times 10^{6} \mathrm{GC}$ per reaction respectively.

175 Quantification of N_Sarbeco assay was performed using 2-fold and 10-fold dilutions

176 (ranging between 2.00 to $2.00 \times 10^{4} \mathrm{GC}$ per reaction) of the Amplirun SARS-CoV-2

177 RNA control (Vircell, Spain). Negative controls (extraction and RT-qPCR assay) were

178 also performed using DNase/RNase free distilled water, following the same conditions

179 as the samples. The extraction efficiency using MNV as proxy averaged $70 \%( \pm 19 \%)$.

180

2.5. SARS-CoV-2 RNA load estimates standardized to population

182 Standardization of SARS-CoV-2 RNA concentration to population and WWTP for each

183 sampling date was performed in accordance with Eq. 1 (Gonzalez et al., 2020). For

184 this calculation only the results from E_Sarbecco assay were used since it was the most sensitive assay.

$$
L_{W W T P}=\frac{C_{W W T P} \times V \times f}{P}
$$

188 where:

189 LWWTP is SARS-CoV-2 RNA load in the WWTP standardized to the population (GC per 190 person in the catchment)

191 CWWTP is the SARS-CoV-2 RNA concentration in samples yielded by the E_Sarbecco assay (GC/L) 
medRxiv preprint doi: https://doi.org/10.1101/2021.07.21.21260905; this version posted July 22, 2021. The copyright holder for this preprint (which was not certified by peer review) is the author/funder, who has granted medRxiv a license to display the preprint in perpetuity. It is made available under a CC-BY-NC-ND 4.0 International license.

$193 \quad V$ is the average daily flow of wastewater in the WWTP during the sampling day

194 ( $\mathrm{m}^{3} /$ day $)$

$195 f$ is the conversion factor between $\mathrm{L}$ and $\mathrm{m}^{3}$

$196 P$ is the estimated population within the WWTP catchment.

197

2.6. Data analysis

199 All data analysis was done with SPSS version 26 (IBM Corporation, US). For statistical analysis, all RT-qPCR below the limit of detection (LOD) were substituted by the LOD with subsequent $\log _{10}$ transformation. The LOD was $3.99,5.52$ and 5.74 GC per

202 reaction for E_Sarbecco, RdRp and N_Sarbecco assays, respectively. Kruskal-Wallis test (KW statistics) was conducted to compare differences in the total number of SARS-CoV-2 RNA detection for each assay, and pairwise comparison was performed with Dunn's test. Mann-Whitney test was used to determine the impact of sampling type (composite versus grab samples collected at hospitals). Spearman rank order correlation was used for calculation of correlation coefficients between the concentrations of SARS-CoV-2 RNA obtained by the three assays and between the number of hospitalized COVID-19 patients and the concentration of SARS-CoV-2 RNA at each hospital.

3. Results and Discussion

3.1. Performance of Charité assays on SARS-CoV-2 quantification in wastewater

215 The first RT-qPCR assays for the detection of SARS-CoV-2 were designed at the

216 beginning of the pandemic following the disclosure of the first SARS-CoV-2 sequence,

217 the designated Charité assays: E_Sarbecco, RdRp (P1 and P2) and N_Sarbecco 
medRxiv preprint doi: https://doi.org/10.1101/2021.07.21.21260905; this version posted July 22, 2021. The copyright holder for this preprint (which was not certified by peer review) is the author/funder, who has granted medRxiv a license to display the preprint in perpetuity. It is made available under a CC-BY-NC-ND 4.0 International license.

218 (Corman et al., 2020). Environmental studies generally rely on the use of a single

219 assay to determine the presence of a target (La Rosa and Muscillo, 2013). However,

220 due to sensitivity and specificity issues the WBE studies for SARS-CoV-2 have

221 included multiple gene targets, including the Charité (Wurtzer et al., 2020; Medema et

222 al., 2020; Chavarria-Miró et al., 2020) and the CDC assays (Ahmed et al., 2020;

223 Medema et al., 2020; Randazzo et al., 2020). In the 32-week study reported here, the

224 three assays were compared with respect to detection rates and concentrations to determine the need to run all three assays in future WBE studies.

226 Detections of SARS-CoV-2 RNA were scarcer during the lockdown and reopening 227 months (April-May), with discrepant results among the assays (Fig. 1A). The results of SARS-CoV-2 RNA prevalence for the three assays $(n=404)$, including below and above LOD, coincided in 193 samples. This number dropped to 80 samples when considering just samples with results above the LoD. In 116 samples, detection occurred for two assays and in 95 samples only one assay was detected.

232 Agreement between assays increased and became more consistent as the total number of detections increased, particularly following the end of the lockdown (Fig.

234 1A, B). The E_Sarbecco assay was detected more frequently than the remaining assays, with consistent detections over the 32-week period of sampling. A total of 290, 177, and 100 samples tested positive for E_Sarbecco, RdRp, and N_Sarbecco,

237 respectively. The detection rates for all assays showed statistically significant 238 differences $(\mathrm{KW}=181.45$, degrees of freedom $=2, \rho<0.001)$. There was also statistical difference in the number of detections in the pair-wise comparison between individual assays ( $\rho<0.001$, for all assays). The number of detections for $N \_$Sarbecco assay was

241 significantly lower than for the other two assays, possibly due to the higher limit of

242 detection determined for this assay or possible loss of RNA integrity. 
medRxiv preprint doi: https://doi.org/10.1101/2021.07.21.21260905; this version posted July 22, 2021. The copyright holder for this preprint (which was not certified by peer review) is the author/funder, who has granted medRxiv a license to display the preprint in perpetuity. It is made available under a CC-BY-NC-ND 4.0 International license.

243 The positivity rates for RdRp and N_Sarbecco assays increased along with increasing

244 concentrations yielded by the E_Sarbecco assay. At concentrations between $10^{2}$ and

$24510^{4} \mathrm{GC} / \mathrm{L}$, the positivity rate was $20 \%$ and $6 \%$ for the RdRp and N_Sarbecco assays,

246 respectively. For E_Sarbecco assay concentrations above $10^{4} \mathrm{GC} / \mathrm{L}$, the positivity

247 rates increased to $77 \%$ for the RdRp assay and $45 \%$ for the N_Sarbecco assay (Fig.

248 S2).

249 The concentration of N_Sarbecco versus the other two assays in raw wastewater 250 showed only moderate correlation (Spearman rank order correlation $r=0.50$ for N_Sarbecco vs. RdRp; $r=0.56$ for N_Sarbecco vs E_Sarbecco; $\rho<0.01, n=404)$. The correlation between E_Sarbecco and RdRp concentration was significant $(r=0.74$, $\rho<0.01, n=404)$ (Fig. S3). Such figure facilitates the comparison of the distribution of positive and negative results for each pair of assays.

The discrepancies observed amongst E_Sarbeco, RdRp and N_Sarbeco assays agreed with previous reports, not only using the Charité assays but also the CDC protocol (Chavarria-Miró et al., 2020; Corman et al., 2020; Medema et al., 2020;

258 Randazzo et al., 2020; Westhaus et al., 2020).

3.2. Detection of SARS-CoV-2 RNA in hospital wastewater samples

A total of 204 COVID-19 hospital wastewaters have been sampled in the 32-week study period and evaluated for the presence of SARS-CoV-2 RNA. Ninety-seven samples were positive for at least one SARS-CoV-2 assay $(97 / 204 ; 48 \%)$, at concentrations ranging from $10^{3}$ to $10^{6} \mathrm{GC} / \mathrm{L}$ (Fig. S4). The percentage of positive samples varied from $24 \%$ (HSS) to $85 \%$ (HCC). The Cq values varied between 26.36 and 38.43 for the E_Sarbecco assay, with agreement in detection for the three assays

267 in $62 \%$ of the samples (including samples below the LoD) and in $21 \%$ samples 
medRxiv preprint doi: https://doi.org/10.1101/2021.07.21.21260905; this version posted July 22, 2021. The copyright holder for this preprint (which was not certified by peer review) is the author/funder, who has granted medRxiv a license to display the preprint in perpetuity. It is made available under a CC-BY-NC-ND 4.0 International license .

considering just samples with positive detection $(n=98)$. Although highly relevant, the number of studies reporting the specific detection of this virus in hospital wastewater is very limited (J. Wang et al., 2020; D. Zhang et al., 2020; Gonçalves et al., 2021). Although no quantification was made, J. Wang et al. (2020) and Gonçalves et al. (2021) reported similar Ct values to those obtained in our study. Detection frequency of SARS-CoV-2 RNA in hospital wastewater increased by the end of the study, when the number of cases in Portugal increased steeply and a high number of hospital beds were being occupied with COVID-19 patients (Fig. 2). From the end of the lockdown to schools reopening and return to partial face-to-face work (April through midSeptember), the number of hospitalized COVID-19 cases decrease from an average of 60 to 3 in HSS and from 73 to 5 in HSO, increasing to 115 and 162 in November, respectively. As for HCC, the average monthly number of hospitalized COVID-19 cases remained stable from April to July (average ranging between 48 and 61 in April and June, respectively), decreasing during the month of August (30) only to increase again in September. By the end of the sampling period, the average number of hospitalized COVID-19 cases increased to 114 .

Correlation analysis was used to investigate the quantitative relation of the SARSCoV-2 RNA concentration to the number of hospitalized COVID-19 cases in each hospital. No correlation was found in HCC and only moderate association was obtained for the other two hospitals (Spearman rank order correlation $r=0.57$ for HSS and $r=0.60$ for HSO; all $\rho<0.01)$. During the phase with lower number of hospitalized COVID-19 cases at HSS, most of the samples collected were below the LOD, a similar result to that observed in HSO hospital (Fig. 2). On the other hand, SARS-CoV-2 RNA detection at HCC was consistent throughout the study. Sporadic detection of SARSCoV-2 RNA during this phase could be attributed not only to the low number of 
medRxiv preprint doi: https://doi.org/10.1101/2021.07.21.21260905; this version posted July 22, 2021. The copyright holder for this preprint (which was not certified by peer review) is the author/funder, who has granted medRxiv a license to display the preprint in perpetuity. It is made available under a CC-BY-NC-ND 4.0 International license.

hospitalized COVID-19 patients but also to the different sampling strategy. While HCC samples were composite, grab samples were taken at the other two hospitals. Statistically significant differences $(\rho<0.001$; Mann-Whitney $U$ test) were determined between composite and grab samples. Composite sampling provides a better representation of a heterogenous sample than grab samples tested separately as the variance between samples decreases and the analytical results reflect more thoroughly the real composition of the sample. Automated systems (composite sampling) are commonly used for chemical analysis of water in industrial and public health applications (U.S. Geological Survey, 2006, 2010; Baird et al., 2017). Composite sampling has also been widely used to analyze trace contaminants such as mycotoxins in foods and to determine microbial populations in soil and water (Jarvis, 2007; Cornman et al., 2018). However, for quantification purposes, composite sampling has not been routinely applied in microbiological analysis of water due to a possible dilution effect. This paradigm has shifted with SARS-CoV-2, with this respiratory virus being found only in approximately $50 \%$ of the stools of infected patients at varying concentrations $\left(10^{2}\right.$ to $10^{8}$ per gram of stool) (Lescure et al., 2020; Pan et al., 2020; Wölfel et al., 2020; Y. Wu et al., 2020; Xu et al., 2020). Even if composite sampling is not paramount in WWTP settings, in single, point locations (such as hospital wastewaters) it may have a deeper impact with the results from this study corroborating the initial hypothesis, as a lower percentage of positive samples were obtained for the hospitals where grab samples were taken. 
medRxiv preprint doi: https://doi.org/10.1101/2021.07.21.21260905; this version posted July 22, 2021. The copyright holder for this preprint (which was not certified by peer review) is the author/funder, who has granted medRxiv a license to display the preprint in perpetuity. It is made available under a CC-BY-NC-ND 4.0 International license .

317 A total of 404 raw wastewater were collected between April 27 and December 2, 2020

318 and monitored for the presence of SARS-CoV-2 RNA. Concentration in positive samples, for E_Sarbecco assay, varied generally between $10^{3}$ and $10^{5} \mathrm{GC} / \mathrm{L}$ (Fig. 3).

Table 2 shows SARS-CoV-2 RNA concentrations and percentage of positive samples discriminated by WWTP. The prevalence of SARS-CoV-2 RNA varied between 51\% in SE and $85 \%$ in BE and GU, with WWTP located in LVT conveying the highest number of positive detections.

The concentrations found in this study are in line with those documented in the US, and The Netherlands (Gonzalez et al., 2020; Medema et al., 2020; Sherchan et al., 2020). Nonetheless, studies developed in Spain and France documented concentrations at least two orders of magnitude superior to the mean concentrations observed in this study (Randazzo et al., 2020; Wurtzer et al., 2020). The differences found between studies may result from a multitude of factors, including disease prevalence, but are more probably related to the variability in the workflows including detection assays.

\subsection{Regional distribution of SARS-CoV-2 RNA concentration}

336 This study was conducted during 32-weeks (eight months) comprising the end of

337 lockdown (April) and consecutive reopening stages (May), full reopening with online classes for students and partial face-to-face work (June), the vacation period (July and August), schools reopening and return to partial face-to-face work (mid-September)

340 (Fig. S5). The new number of reported cases decreased sharply from April (mean, 341570 ) to May (mean, 249), increasing again in June (mean, 325), according to Reports 
medRxiv preprint doi: https://doi.org/10.1101/2021.07.21.21260905; this version posted July 22, 2021. The copyright holder for this preprint (which was not certified by peer review) is the author/funder, who has granted medRxiv a license to display the preprint in perpetuity. It is made available under a CC-BY-NC-ND 4.0 International license .

342 from the Portuguese Health Authority (DGS, 2020). The average number of new cases

343 decreased in July (mean, 286) and August (mean, 224) only to increase again in

344 September (mean, 605), October (mean, 2,192) and November $(5,058)$.

345 Fig. 4 shows the load of SARS-CoV-2 RNA, by date, normalized to population in the 346 service area of each WWTP. SARS-CoV-2 RNA detection in WWTP for the LVT region 347 showed lower percentages of detection during April-May, increase in the frequency of 348 detection in June, decrease for the months of July, August and mid-September, and a 349 steep increase from mid-September onwards (Fig. S6). The viral load in the LVT 350 region in this region followed a similar trend to that of the prevalence of the virus.

351 Nonetheless, the detection of SARS-CoV-2 RNA in WWTP from LVT region remained 352 high after the end of lockdown. SARS-CoV-2 RNA load in the north region of the country (GA and SE) remained stable during the period comprising April to midSeptember, sharply increasing afterwards following the trends observed in the syndromic surveillance (Fig. S6). Occasional detections were observed during the lockdown and following periods with a gradual increase in the frequency of detection until mid-September. Upon school reopening, return to partial face-to-face work, a steep increase occurred in the SARS-CoV-2 RNA load in all locations. During prelockdown and lockdown, the North region was the most affected by COVID-19, a pattern that shifted following the reopening with the great Lisbon area becoming the main contributor to the increase in the number of COVID-19 cases observed 362 throughout May and June (Fig. S7). Altogether, the cumulative number of COVID-19 cases increased at a slow pace from the end of April until the beginning of October, with a noticeable increase at this stage mainly due to the new spike in cases registered

365 in the North region. Overall, and until October 25, 2020, Lisbon and Sintra, both in 366 LVT, had the highest number of confirmed COVID-19 cases $(9,202$ and 7,454 , 
medRxiv preprint doi: https://doi.org/10.1101/2021.07.21.21260905; this version posted July 22, 2021. The copyright holder for this preprint (which was not certified by peer review) is the author/funder, who has granted medRxiv a license to display the preprint in perpetuity. It is made available under a CC-BY-NC-ND 4.0 International license.

respectively), followed by Amadora, Loures, (3,722, and 4,164, respectively), also in the LVT region. In the North region, Vila Nova de Gaia had the highest number of confirmed cases.

370 Data from Fig. 4 can be used for comparison with existing outbreaks reported by the

371 health department. For instance, the increase in the detection in the BE service area 372 documented during June was likely caused by outbreaks in Sacavém-Prior Velho, 373 Camarate-Unhos-Apelação and Santa Clara civil parishes. Such projection can also show trends in viruses spread over time within localized populations, not only from symptomatic but also from asymptomatic, pre-symptomatic and post-symptomatic.

376 Such representation shows that although the number of clinically tested cases in the 377 population was more consistent, the viral concentration remained mostly heterogeneous with a vast influence from localized hotspots of infection.

Fig. 5 illustrates the combined loads of SARS-CoV-2 RNA, over time, in the chosen WWTP service areas. The concentrations of SARS-CoV-2 RNA (E_Sarbecco) from all five WWTP were merged daily to obtain an estimation of the concentrations in the regions tested.

383 The trend combined for the regions was equivalent to the trends observed in the

384 clinical surveillance. It is evident from the present data that the reopening phase, in May, corresponded to an increment in the viral load, which is in accordance with the

386 increase observed, in Portugal, in the number of new daily COVID-19 reported cases.

387 Following this phase, the country entered the summer vacation period, with a slight decrease on viral load. The third and final stage of viral loading, in this study, occurred after the reopening of schools and return to partial face-to-face work. At this stage,

390 viral loading increased gradually in parallel with the rise of new daily COVID-19 cases

391 in the country. 
medRxiv preprint doi: https://doi.org/10.1101/2021.07.21.21260905; this version posted July 22, 2021. The copyright holder for this preprint (which was not certified by peer review) is the author/funder, who has granted medRxiv a license to display the preprint in perpetuity. It is made available under a CC-BY-NC-ND 4.0 International license .

392 The pattern similarity between the number of new COVID-19 cases reported daily,

393 provided by clinical testing, and the load of SARS-CoV-2 RNA in raw wastewater

394 further proves the usefulness of WBE for SARS-CoV-2, or another potential future

395 pandemic. Such representation (Fig. 5B), could therefore be integrated with syndromic

396 surveillance data, as an early-warning system for the increase of the number of

397 infected individuals within the community.

398 Results from individual testing should be the most accurate measure of transmission

399 and disease occurrence in the population, but the scale of testing (spatial and

400 temporal) necessary to have accurate information and to be able to follow the spread

401 of the virus in the population is unrealistic and economically impracticable for most

402 countries. Additionally, continuous testing indispensable for the effective control of the

403 disease is economically and timely challenging. Wastewater monitoring represents

404 testing thousands of infected people simultaneously rather than a single person and

405 is complimentary to syndromic surveillance of COVID-19. The knowledge provided by

406 the analysis of wastewater can, therefore, be employed as an impartial surveillance

407 tool, reflecting more closely the health of a population. Moreover, wastewater may also

408 allow for a precocious detection of new SARS-CoV-2 variants circulating in the

409 community (Crits-Christoph et al., 2021; Jahn et al., 2021). WBE for SARS-CoV-2, and

410 future emerging pathogens, has the potential to target the need for more localized

411 clinical testing, facilitating the detection of occasional hotspots of infection likely to

412 occur as this or other pandemics take place. It is scalable, with a fast turnaround, and

413 economically competitive. WBE could be useful in school or nursing home settings, to

414 evaluate the presence and spread of the viruses instead of testing hundreds or

415 thousands of individuals. Additionally, WBE can be a very powerful tool in countries

416 with limited resources, to inform decisions and in aiding with policy making 
medRxiv preprint doi: https://doi.org/10.1101/2021.07.21.21260905; this version posted July 22, 2021. The copyright holder for this preprint (which was not certified by peer review) is the author/funder, who has granted medRxiv a license to display the preprint in perpetuity.

4. Conclusion

- SARS-CoV-2 RNA was detected in raw wastewater of all five studied WWTP at concentrations similar to those reported in other studies. Data reflected the different epidemiological stages, including surges and decreases, observed with the syndromic surveillance.

- The selection of sampling methods, composite vs grab, may have a massive impact in the results and potential use of WBE for SARS-CoV-2 or for any other future pandemic, particularly in situations where low circulation of the virus is expected.

- The total load of SARS-CoV-2 RNA in raw wastewater followed a similar trend to the number of daily new COVID-19 reported cases. Considering data, the use of viral loading would be a more suitable approach than gene-based approaches to use in WBE settings. We consider using the number of daily new COVID-19 reported cases a more suitable approach to simply comparing with cumulative number of cases especially when dealing with several waves of infection.

- Data from this study corroborates the plausibility and timeliness of the development and deployment of a nationwide WBE system for SARS-CoV-2 (naturally, ideally scalable for future pandemics) to aid local health and

\section{$438 \quad$ Funding}

439 This work was supported by Programa Operacional de Competitividade e Internacionalização (POCl)

440 (FEDER component), Programa Operacional Regional de Lisboa, and Programa Operacional Regional do Norte (Project COVIDETECT, ref. 048467). 
medRxiv preprint doi: https://doi.org/10.1101/2021.07.21.21260905; this version posted July 22, 2021. The copyright holder for this preprint

(which was not certified by peer review) is the author/funder, who has granted medRxiv a license to display the preprint in perpetuity.

It is made available under a CC-BY-NC-ND 4.0 International license.

\section{Declaration of Competing Interest}

444 The authors declare that they have no known competing financial interests or personal relationships

445 that could have appeared to influence the work reported in this paper.

446

447

Acknowledgements

448 We thank all the workers from Águas de Portugal Group who contributed to wastewater sampling. We

449 also thank the project's Advisory Board (EPAL, Águas do Douro e Paiva, National Environment Agency

450 (APA), National Health Authority (DGS) and Portuguese Water and Waste Services Regulation

451 Authority (ERSAR).

452 Strategic funding of Fundação para a Ciência e a Tecnologia (FCT), Portugal, to cE3c and BiolSI

453 Research Units (UIDB/00329/2020 and UIDB/04046/2020] is also gratefully acknowledged. 
medRxiv preprint doi: https://doi.org/10.1101/2021.07.21.21260905; this version posted July 22,2021 . The copyright holder for this preprint (which was not certified by peer review) is the author/funder, who has granted medRxiv a license to display the preprint in perpetuity.

References

455

Ahmed, W., Bertsch, P.M., Bivins, A., Bibby, K., Farkas, K., Gathercole, A., Haramoto,

E., Gyawali, P., Korajkic, A., McMinn, B.R., Mueller, J.F., Simpson, S.L., Smith, W.J.,

Symonds, E.M., Thomas, K.V., Verhagen, R., Kitajima, M., 2020. Comparison of virus

concentration methods for the RT-qPCR-based recovery of murine hepatitis A virus,

a surrogate for SARS-CoV-2 from untreated wastewater. Sci. Total Environ. 739, 139960. doi: 10.1016/j.scitotenv.2020.139960

Baert, L., Wobus, C.E., Van Coillie, E., Thackray, L.B., Debevere, J., Uyttendaele, M., 2008. Detection of Murine Norovirus 1 using plaque assay, transfection assay, and real-time reverse-transcription-PCR before and after heat exposure. Appl. Environ. Microbiol. 74 (2), 543-546. doi: 10.1128/AEM.01039-07

Baird, R.B., Eaton, A.D., Rice, E.W., 2017. Standard Methods for the Examination of Water and Wastewater, $23^{\text {rd }}$ ed. American Public Health Association, Washington DC.

Blanco, A., Abid, I., Al-Otaibi, N., Pérez-Rodríguez, F.J., Fuentes, C., Guix, S., Pintó,

R.M., Bosch, A., 2020. Glass wool concentration and optimization for the detection of enveloped and non-enveloped waterborne viruses. Food Environ. Virol. 11 (2), 184192. doi: $10.1007 / \mathrm{s} 12560-019-09378-0$

Chavarria-Miró, G., Anfruns-Estrada, E., Guix, S., Paraira, M., Galofré, B., Sánchez, G., Pintó, R., Bosch, A., 2020. Sentinel surveillance of SARS-CoV-2 in wastewater anticipates the occurrence of COVID-19 cases. medRxiv doi: $10.1101 / 2020.06 .13 .20129627$

475 Choi, P.M., Tscharke, B.J., Donner, E., O’Brien, J.W., Grant, S.C., Kaserzon, S.L., 476 Mackie, R., O’Mally, E., Crosbie, N.D., Thomas, K.V., Mueller, J.F., 2018. Wastewater477 based epidemiology biomarkers: Past, present and future. Trends Analyt. Chem. 105, 453-469. doi: 10.1016/j.trac.2018.06.004 
medRxiv preprint doi: https://doi.org/10.1101/2021.07.21.21260905; this version posted July 22, 2021. The copyright holder for this preprint (which was not certified by peer review) is the author/funder, who has granted medRxiv a license to display the preprint in perpetuity. It is made available under a CC-BY-NC-ND 4.0 International license.

479 Corman, V.M., Landt, O., Kaiser, M., Molenkamp, R., Meijer, A., Chu, D.K.W., 480 Bleicker, T., Brünink, S., Schneider, J., Schmidt, M.L., Mulders, D., Haagmans, B.L., 481 van der Veer, B., van der Brink, S., Wijsman, L., Goderski, G., Romette, J.-L., Ellis, J., 482 Zambon, M., Peiris, M., Goossens, H., Reusken, C., Koopmans, M., Drosten, C., 2020. 483 Detection of 2019 novel coronavirus (2019-nCoV) by real-time RT-PCR. Euro Surveill. 484 25 (3), 2000045. doi: 10.2807/1560-7917.ES.2020.25.3.2000045

485 Cornman, R.S., McKenna, J.E. Jr., Fike, J., Oyler-McCance, S.J., Johnson, R., 2018. An experimental comparison of composite and grab sampling of stream water for metagenetic analysis of environmental DNA. PeerJ 6:e5871. doi: 10.7717/peerj.5871

488 Crits-Christoph, A., Kantor, R.S., Olm, M.R., Whitney, O.N., Al-Shayeb, B., Lou, Y.C., 489 Flamholz, A., Greenwald, H., Hinkle, A., Hetzel, J., Spitzer, S., Koble, J., Tan, A., 490 Hyde, F., Schroth, G., Kuersten, S., Banfield, J.F., Nelson, K.L., 2021. Genome sequencing of sewage detects regionally prevalent SARS-CoV-2 variants. mBio 12(1): e02703-20. doi: 10.1128/mBio.02703-20

DGS, 2020. Novo Coronavírus - COVID-19: relatório da situação. https://covid19.minsaude.pt/relatorio-de-situacao/ (last accessed 10 March 2020). Gonçalves, J., Koritnik, T., Mioč, V., Trkov, M., Bolješič, M., Berginc, N., Prosenc, K., Kotar, T., Paragi, M., 2021. Detection of SARS-CoV-2 RNA in hospital wastewater 497 from a low COVID-19 disease prevalence area. Sci. Total Environ. 755 (Part 2), 498143226.

499 Gonzalez, R., Curtis, K., Bivins, A., Bibby, A., Weir, M.H., Yetka, K., Thompson, H., 500 Keeling, D., Mitchell, J., Gonzalez, D., 2020. COVID-19 surveillance in Southeastern 501 Virginia using wastewater-based epidemiology. Water Res. 186, 116296. doi: 
medRxiv preprint doi: https://doi.org/10.1101/2021.07.21.21260905; this version posted July 22, 2021. The copyright holder for this preprint (which was not certified by peer review) is the author/funder, who has granted medRxiv a license to display the preprint in perpetuity.

He, X., Lau, E.H.Y., Wu, P., Deng, X., Wang, J., Hao, X., Lau, Y.C., Wong, J.Y., Guan,

Y.G., Tan, X., Mo, X., Chen, Y., Liao, B., Chen, W., Hu, F., Zhang, Q., Zhong, M., Wu,

in viral shedding and transmissibility of COVID-19. Nat. Med. 26, 672-675. doi:

$10.1038 / s 41591-020-0869-5$

508 Hovi, T., Shulman, L.M., Van der Avoort, H., Deshpande, J., Roivainen, M., De

509 Gourville, E.M., 2012. Role of environmental poliovirus surveillance in global polio

510 eradication and beyond. Epidemiol. Infect. 140(1), 1-13. doi:

512 Jahn, K., Dreifuss, D., Topolsky, I., Kull, A., Ganesanandamoorthy, P., Fernandez-

513 Cassi, X., Bänziger, C., Stachler, E., Furhmann, L., Jablonski, K.P., Chen, C., Aquino,

514 C., Stadler, T., Ort, C., Kohn, T., Julian, T.R., Beerenwinkel, N., 2021. Detection of

SARS-CoV-2 variants in Switzerland by genomic analysis of wastewater samples. medRxiv. doi: 10.1101/2021.01.08.21249379

517 Jarvis, B., 2007. On the compositing of samples for qualitative microbiological testing.

518 Lett. Appl. Microbiol. 45, 592-598. doi: 10.1111/j.1472-765X.2007.02237.x

519 Koopmans, J.S., Henry, C.J., Park, J.H., Eisenberg, M.C., Ionides, E.L., Eisenberg, is stopped. Epidemics 20, 21-36. doi: 10.1016/j.epidem.2017.02.013

La Rosa, G., Muscillo, M., 2013. Molecular detection of viruses in water and sewage, in: Cook, N. (Ed.), Viruses in Food and Water: Risks, Surveillance and Control.

Woodhead Publishing Limited. Cambridge, pp. 97-125.

Lescure, F.-X-. Bouadma, L., Nguyen, D., Parisey, M., Wicky, P.-H., Behillil, S.,

526 Gaymard, A., Bouscambert-Duchamp, M., Donati, F., Le Hingrat, Q., Enouf, V.,

527 Houhou-Fidouh, N., Valette, M., Mailles, A., Lucet, J.-C., Mentre, F., Duval, X., 
medRxiv preprint doi: https://doi.org/10.1101/2021.07.21.21260905; this version posted July 22, 2021. The copyright holder for this preprint (which was not certified by peer review) is the author/funder, who has granted medRxiv a license to display the preprint in perpetuity.

528 Descamps, D., Malvy, D., Timsit, J.-F., Lina, B., van-der-Werf, S., Yazdanpanah, Y.,

529 2020. Clinical and virological data of the first cases of COVID-19 in Europe: a case

530 series. Lancet Infect. Dis. 20 (6), 697-706. doi: 10.1016/S1473-3099(20)30200-0

531 Mandi, K.D., Overhage, J.M., Wagner, M.W., Lober, W.B., Sebastiani, P., Mostashari,

532 F., Pavlin, J.A., Gesteland, P.H., Treadwell, T., Koski, E., Hutwagner, L., Buckeridge,

533 D.L., Aller, R.D., Grannis, S., 2004. Implementing syndromic surveillance: a practical

534 guide informed by the early experiences. J. Am. Med. Inform. Assoc. 11(2), 141-150. doi: 10.1197/jamia.M1356

536 Medema, G., Heijnen, L., Elsinga, G., Italiaander, R., Brouwer, A., 2020. Presence of

537 SARS-Coronavirus-2 RNA in sewage and correlation with reported COVID-19

538 prevalence in the early stage of the epidemic in The Netherlands. Environ. Sci.

539 Technol. Lett. doi: 10.1021/acs.estlett.0c00357

540 Meselson, M., 2020. Droplets and aerosols in the transmission of SARS-CoV-2. N.

541 Eng. J. Med. 382(21), 2063. doi: 10.1056/NEJMc2009324

542 Pan, Y., Zhang, D., Yang, P., Poon, L.L.M., Wang, Q., 2020. Viral load of SARS-CoV-

5432 in clinical samples. Lancet Infect. Dis. 20 (4), 411-412. doi: 10.1016/S1473$544 \quad 3099(20) 30113-4$

545 Randazzo, W., Truchado, P., Ferranfo, E.C., Simon, P., Allende, A., Sanchez, G.,

546 2020. SARS-CoV-2 RNA titers in wastewater anticipated COVID-19 occurrence in a

547 low prevalence area. Water Res. 181, 115942. doi: 10.1016/j.watres.2020.115942

548 Reddy, D., 2010. Responding to pandemic (H1N1) 2009 influenza: the role of 549 oseltamivir. J. Antimicrob. Chemother. 65 (suppl. 2), ii35-ii40. doi: 10.1093/jac/dkq014.

550 RTP, 2020. 'COVID-19. Ministra admite que Portugal entra em "fase de crescimento 551 exponencial". $\quad$ https://www.rtp.pt/noticias/mundo/covid-19-ministra-admite-que- 
medRxiv preprint doi: https://doi.org/10.1101/2021.07.21.21260905; this version posted July 22, 2021. The copyright holder for this preprint (which was not certified by peer review) is the author/funder, who has granted medRxiv a license to display the preprint in perpetuity.

552 portugal-entra-em-fase-de-crescimento-exponencial_e1212035. Last accessed: 16

553 March 2021.

554 Santos, R., Monteiro, S., 2013. Epidemiology, control, and prevention of emerging 555 zoonotic viruses, in: Cook, N. (Ed.), Viruses in Food and Water: Risks, Surveillance 556 and Control. Woodhead Publishing Limited. Cambridge, pp. 442-457.

557 Sherchan, S.P., Shahin, S., Ward, L.M., Tandukar, S., Aw, T.G., Schmitz, B., Ahmed, 558 W., Kitajima, M., 2020. First detection of SARS-CoV-2 RNA in wastewater in North 559 America: a study in Louisiana, USA. Sci. Total Environ. 743, 140621. doi: $560 \quad$ 10.1016/j.scitotenv.2020.140621

561 Singer, A.C., Järhult, J.D., Grabic, R., Khan, G.A., Fedorova, G., Fick, J., Lindberg,

562 R.H., Bowes, M.J., Olsen, B., Söderström, H., 2013. Compliance to oseltamivir among 563 two populations in Oxfordshire, United Kingdom affected by influenza $A(H 1 N 1) p d m 09$,

564 November, 2009 - a waste water epidemiology study. PLoS One 8, e60221. doi: 10.1371/journal.pone.0060221

U.S. Geological Survey, 2006. Techniques and methods 1-D3: guidelines and

567 standard procedures for continuous water-quality monitors: station operation, record 568 computation, and data reporting. https://pubs.usgs.gov/tm/2006/tm1D3/ (last accessed 7 September 2020)

570 U.S. Geological Survey, 2010. Scientific investigations report 2010-5008: use of 571 continuous monitors and autosamples to predict unmeasured water-quality 572 constituents in tributaries of the Tualatin River, Oregon. 573 https://pubs.usgs.gov/sir/2010/5008/lot.html (last accessed 7 September 2020).

574 Wang, J. Feng, H., Zhang, S., Ni, Z., Ni, L., Chen, Y., Zhuo, L., Zhong, Z., Qu, T., 575 2020. SARS-CoV-2 RNA detection of hospital isolation wards hygiene monitoring 
medRxiv preprint doi: https://doi.org/10.1101/2021.07.21.21260905; this version posted July 22, 2021. The copyright holder for this preprint (which was not certified by peer review) is the author/funder, who has granted medRxiv a license to display the preprint in perpetuity. It is made available under a CC-BY-NC-ND 4.0 International license.

during the Coronavirus Disease 2019 outbreak in a Chinese hospital. Int. J. Inf. Dis. 94, 103-106. doi: 10.1016/j.scitotenv.2020.139652

Westhaus, S., Weber, F.-A., Schiwy, S., Linnemann, V., Brinkmann, M., Widera, M., Greve, C., Janke, A., Hollert, H., Wintgens, T., Ciesek, S., 2020. Detection of SARSCoV-2 in raw and treated wastewater in Germany - Suitability for COVID-19 surveillance and potential transmission risks. Sci. Total Environ. 751, 141750. doi: 10.1016/j.scitotenv.2020.141750

Wigginton, K.R., Ye, Y., Ellenberg, R.M., 2015. Emerging investigators series: the source and fate of pandemic viruses in the urban water cycle. Environ. Sci.: Water Res. Technol. 1: 735.

Wölfel, R., Corman, V.M., Guggemos, W., Seilmaier, M., Zange, S., Müller, M.A., Niemeyer, D., Jones, T.C., Vollmar, P., Rothe, C., Hoelscher, M., Bleicker, T., Brünink, S., Schneider, J., Ehmann, R., Zwirglmaier, K., Drosten, C., Wendtner, C., 2020. Virological assessment of hospitalized patients with COVID-2019. Nature 581, 465469. doi: 10.1038/s41586-020-2196-x

WHO, 2015. Guidelines on Environmental Surveillance for Detection of Polioviruses, Working Draft. Geneva, Switzerland. http://polioeradication.org/wpcontent/uploads/2016/07/GPLN_GuidelinesES_April2015.pdf

Wu, F., Xiao, A., Zhang, J., Gu, X., Lee, W.L., Kauffman, K., Hanage, W., Matus, M., Ghaeli, N., Endo, N., Duvallet, C., Moniz, K., Erickson, T., Chai, P., Thompson, J., Alm, E., 2020. SARS-CoV-2 titers in wastewater are higher than expected from clinically confirmed cases. MedRxiv doi: 10.1101/2020.04.05.20051540 Wu, Y., Guo, C., Tang, L., Hong, Z., Zhou, J., Dong, X., Yin, H., Xiao, Q., Tang, Y., Qu, X., Kuang, L., Fang, X., Mishra, N., Lu, J., Shan, H., Jiang, G., Huang, X., 2020. 
medRxiv preprint doi: https://doi.org/10.1101/2021.07.21.21260905; this version posted July 22, 2021. The copyright holder for this preprint (which was not certified by peer review) is the author/funder, who has granted medRxiv a license to display the preprint in perpetuity.

600 Prolonged presence of SARS-CoV-2 viral RNA in faecal samples. Lancet

601 Gastroenterol. Hepatol. 5 (5), 434-435. doi: 10.1016/S2468-1253(20)30083-2

602 Wurtzer, S., Marechal, V., Mouchel, J.-M., Maday, Y., Teyssou, R., Richard, E.,

603 Almayrac, J.L., Moulin, L., 2020b. Evaluation of lockdown impact on SARS-CoV-2

604 dynamics through viral genome quantification in Paris wastewater. MedRxiv doi:

606 Xu, Y., Li, X., Zhu, B., Liang, H., Fang, C., Gong, Y., Guo, Q., Sun, X., Zhao, D., Shen,

607 J., Zhang, H., Liu, H., Xia, H., Tang, J., Zhang, K., Gong, S., 2020. Characteristics of 608 pediatric SARS-CoV-2 infection and potential evidence for persistent fecal viral 609 shedding. Nat. Med. 26 (4), 502-505. doi: 10.1038/s41591-020-0817-4

610 Young, B.E., Fong, S.-W., Chan, Y.-H. Mak, T.-M., Ang, L., Anderson, D., Lee, C., 611 Amrun, S., Lee, B., Goh, Y., Su, Y., Wei, W., Kalimuddin, S., Chai, L., Pada, S., Tan, 612 S., Sun, L., Parthasarathy, P., Chen, Y., Barkham, T., Lin, R., Maurer-Stroh, S., Leo, 613 Y.-S., Wang, L.-F., Renia, L., Lee, V., Smith, G., Lye, D., Ng, L., 2020. Effect of a major 614 deletion in the SARS-CoV-2 genome on the severity of infection and the inflammatory 615 response: an observational cohort study. The Lancet 396(10251), 603-611. doi: 10.1016/S0140-6736(20)31757-8

617 Zang, R., Castro, M., McCune, B., Zeng, Q. Rothlauf, P., Sonnek, N., Liu, Z., Brulois, 618 K., Wang, X., Greenberg, H., Diamond, M., Ciorba, M., Whelan,S., Ding, S., 2020. 619 TMPRSS2 and TMPRSS4 promote SARS-CoV-2 infection of small intestinal 620 enterocytes. Sci. Immunol. 5(47), eabc3582. doi: 10.1126/sciimmunol.abc3582

621 Zuccato, E., Chiabrando, C., Castiglioni, S., Calamari, D., Bagnati, R., Schiarea, S., 622 Fanelli, R., 2005. Cocaine in surface waters: a new evidence-based tool to monitor community drug abuse. Environ. Health 4, 14. doi: 10.1186/1476-069X-4-14 
medRxiv preprint doi: https://doi.org/10.1101/2021.07.21.21260905; this version posted July 22, 2021. The copyright holder for this preprint (which was not certified by peer review) is the author/funder, who has granted medRxiv a license to display the preprint in perpetuity. It is made available under a CC-BY-NC-ND 4.0 International license .

625

626

Table 1.

Primers and probes used in this study

\begin{tabular}{|c|c|c|c|}
\hline Assay & Sequence $\left(5^{\prime}-3^{\prime}\right)^{a}$ & $\begin{array}{l}\text { Length } \\
\text { (bp) }\end{array}$ & $\begin{array}{l}\text { Location in SARS- } \\
\text { CoV-2 } \\
\text { genome (bp) }\end{array}$ \\
\hline MNV & $\begin{array}{l}\text { F: CACGCCACCGATCTGTTCTG } \\
\text { R: GCGCTGCGCCATCACTC } \\
\text { P: 6FAM-CGCTTTGGAACAATG-MGB }\end{array}$ & 108 & $4,972-5,080$ \\
\hline $\begin{array}{l}\text { SARS-CoV-2: } \\
\text { E_Sarbecco }\end{array}$ & $\begin{array}{l}\text { F: ACAGGTACGTTAATAGTTAATAGCGT } \\
\text { R: ATATTGCAGCAGTACGCACACA } \\
\text { P: 6FAM-ACACTAGCCATCCTTACTGCGCTTCG-BHQ }\end{array}$ & 112 & $26,141-26,253$ \\
\hline $\begin{array}{l}\text { SARS-CoV-2: } \\
\text { RdRp }\end{array}$ & $\begin{array}{l}\text { F: GTGARATGGTCATGTGTGGCGG } \\
\text { R: CARATGTTAAASACACTATTAGCATA } \\
\text { P1: 6FAM-CCAGGTGGWACRTCATCMGGTGATGC-BHQ } \\
\text { P2: 6FAM-CAGGTGGAACCTCATCAGGAGATGC-BHQ }\end{array}$ & 99 & $15,361-15,460$ \\
\hline $\begin{array}{l}\text { SARS-CoV-2: } \\
\text { N_Sarbecco }\end{array}$ & $\begin{array}{l}\text { F: CACATTGGCACCCGCAATC } \\
\text { R: GAGGAACGAGAAGAGGCTTG } \\
\text { P: 6FAM-ACTTCCTCAAGGAACAACATTGCCA-BHQ }\end{array}$ & 127 & $28,555-28,682$ \\
\hline
\end{tabular}

627 a $W$ is $A / T$; $R$ is $G / A ; M$ is $A / C$; $S$ is $G / C$. FAM: 6-carboxyfluorescein; MGB: minor groove binder; BHQ: blackhole 628 quencher.

629

$630 \quad$ Table 2.

631 SARS-CoV-2 RNA concentration and percentage of positive samples in the overall study and in each WWTP

\begin{tabular}{lll}
\hline Sampling location & \% Positive samples & SARS-CoV-2 RNA concentration variation (GC/L) \\
\hline All WWTP & $72(291 / 404)$ & $3.13 \times 10^{3}-8.95 \times 10^{5}$ \\
AL & $82(65 / 79)$ & $3.86 \times 10^{3}-8.17 \times 10^{5}$ \\
BE & $85(74 / 87)$ & $3.13 \times 10^{3}-5.43 \times 10^{5}$ \\
GU & $85(67 / 79)$ & $3.41 \times 10^{3}-8.95 \times 10^{5}$ \\
GA & $56(44 / 79)$ & $3.30 \times 10^{3}-3.93 \times 10^{5}$ \\
SE & $51(41 / 80)$ & $3.29 \times 10^{3}-3.20 \times 10^{5}$ \\
\hline
\end{tabular}

632 
medRxiv preprint doi: https://doi.org/10.1101/2021.07.21.21260905; this version posted July 22,2021 . The copyright holder for this preprint (which was not certified by peer review) is the author/funder, who has granted medRxiv a license to display the preprint in perpetuity. It is made available under a CC-BY-NC-ND 4.0 International license .
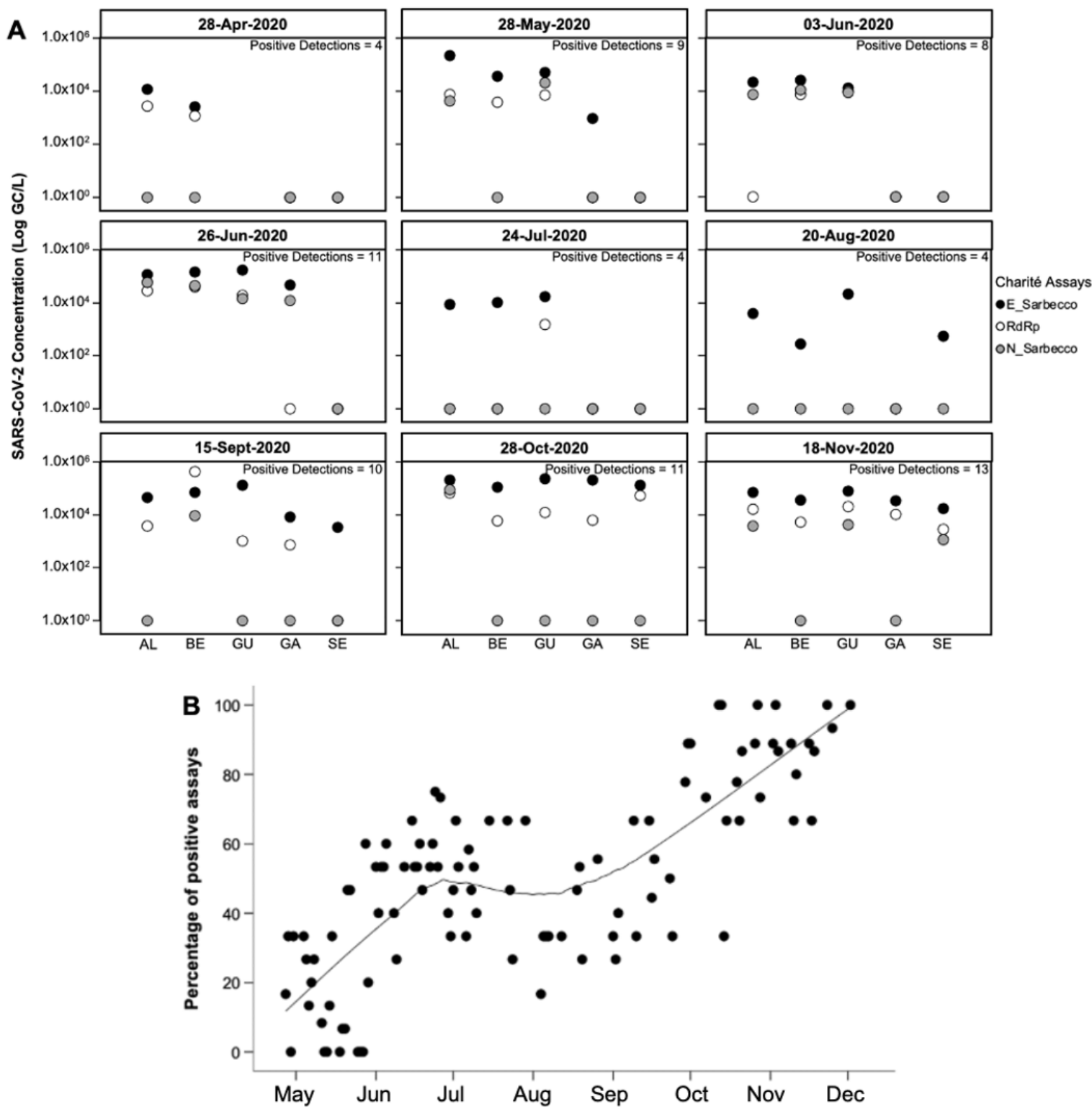

634 Fig. 1. SARS-CoV-2 RNA concentration estimated with Charité assays in selected sampling dates. The 635 concentrations in each WWTP, in selected sampling dates, are depicted on the $x$ axis of the figure. The dates were chosen at (roughly) monthly intervals, starting from April 28, with exception of June 3, which was added because it represented one of the first dates following the complete reopening of the country $(A)$; epidemiological phase (EPI) I: emergency state; EPI II: calamity state; EPI III: contingency and alert state; EPI IV: emergency state. Percentage of positive detection assays across the study period. Obtained with the 3 Charité assays. The trendline was drawn with LOWESS smoothing (B). 


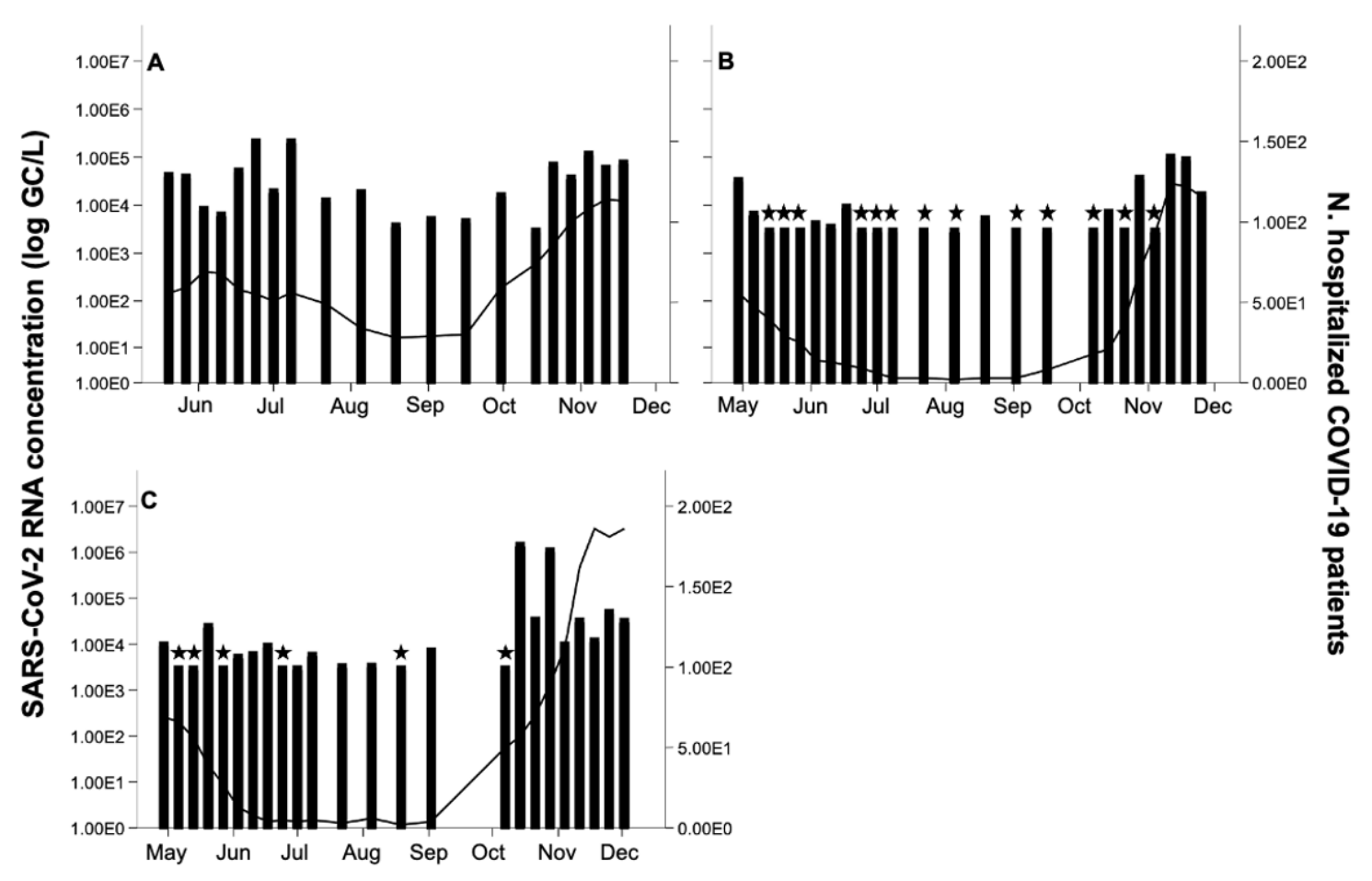

643

644

645

646

Fig. 2. Gene fragment concentration in hospital wastewater (bars), and the number of hospitalized COVID-19 cases (line) in the three hospitals. HCC (A); HSS (B); HSO (C). $\star$ Indicates values below the LoD for E_Sarbecco assay. Values represented in the figures

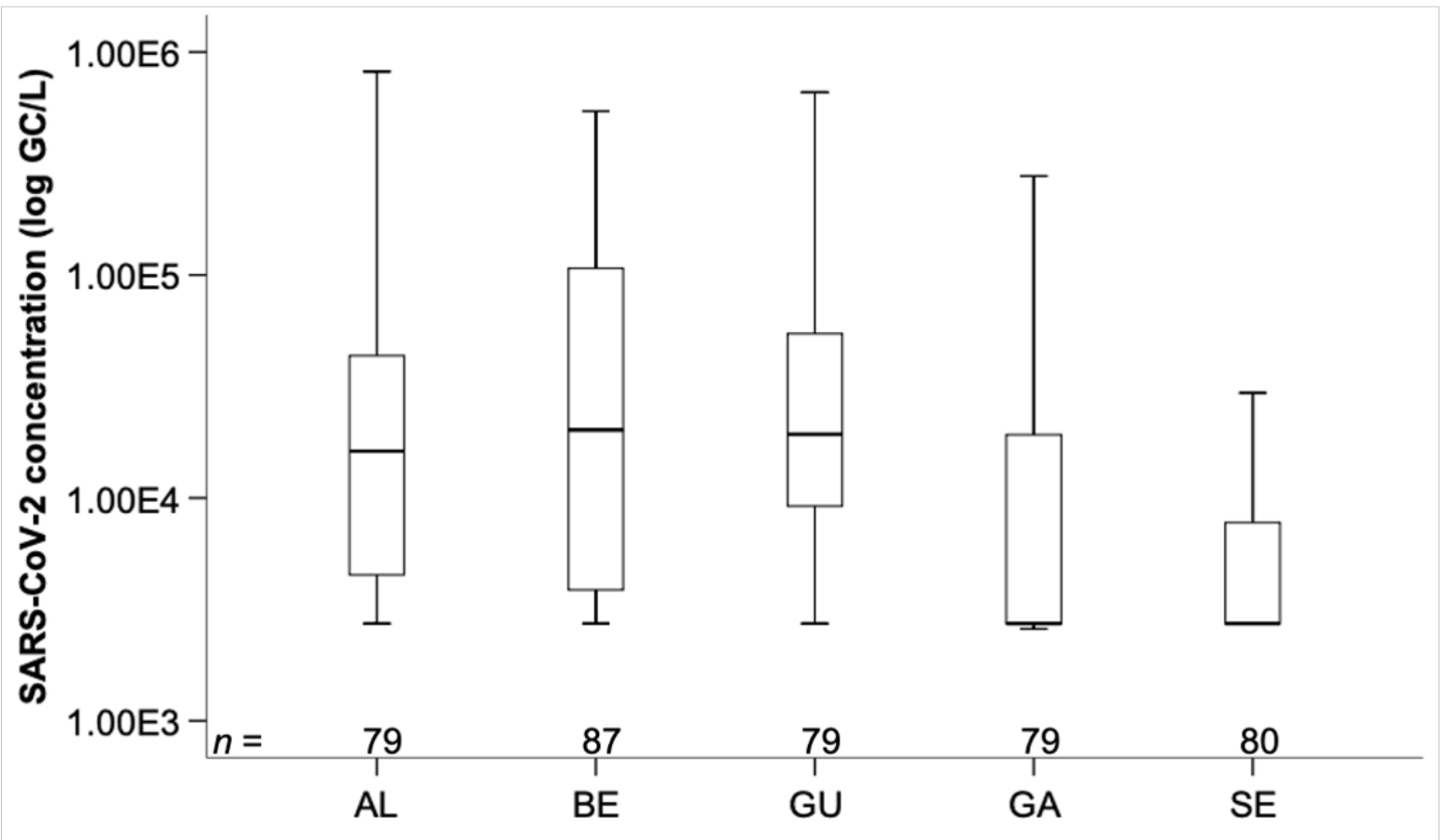

Fig. 3. SARS-CoV-2 concentration in the tested WWTP. AL- Alcântara; BE - Beirolas; GU - Guia; GA - Gaia Litoral; SE - Serzedelo (circles and asterisks represent outliers). 
medRxiv preprint doi: https://doi.org/10.1101/2021.07.21.21260905; this version posted July 22,2021 . The copyright holder for this preprint (which was not certified by peer review) is the author/funder, who has granted medRxiv a license to display the preprint in perpetuity.
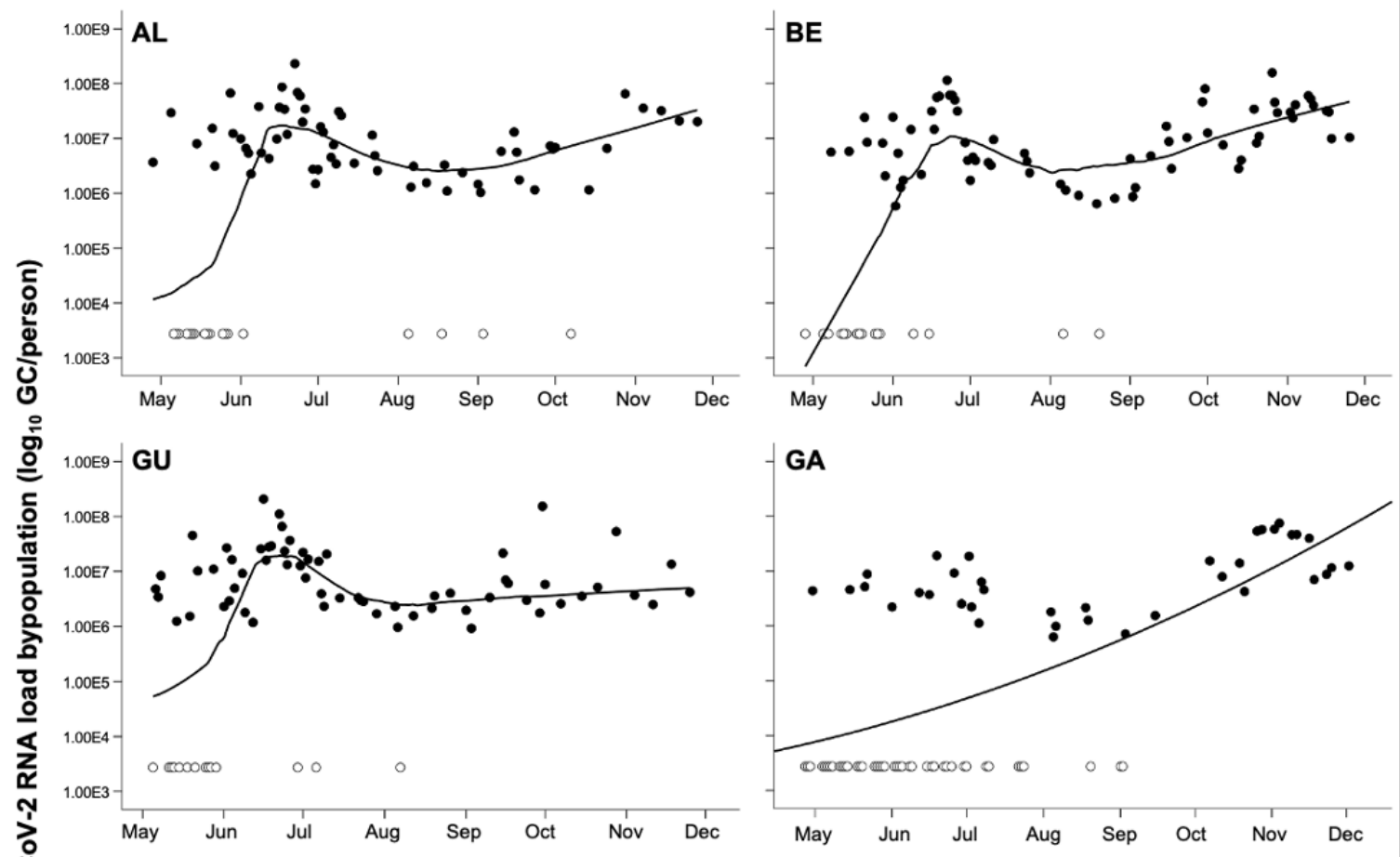

Fig. 4. SARS-CoV-2 RNA load, by date, normalized to the population in the service area of each WWTP. Black 
medRxiv preprint doi: https://doi.org/10.1101/2021.07.21.21260905; this version posted July 22, 2021. The copyright holder for this preprint (which was not certified by peer review) is the author/funder, who has granted medRxiv a license to display the preprint in perpetuity. It is made available under a CC-BY-NC-ND 4.0 International license .
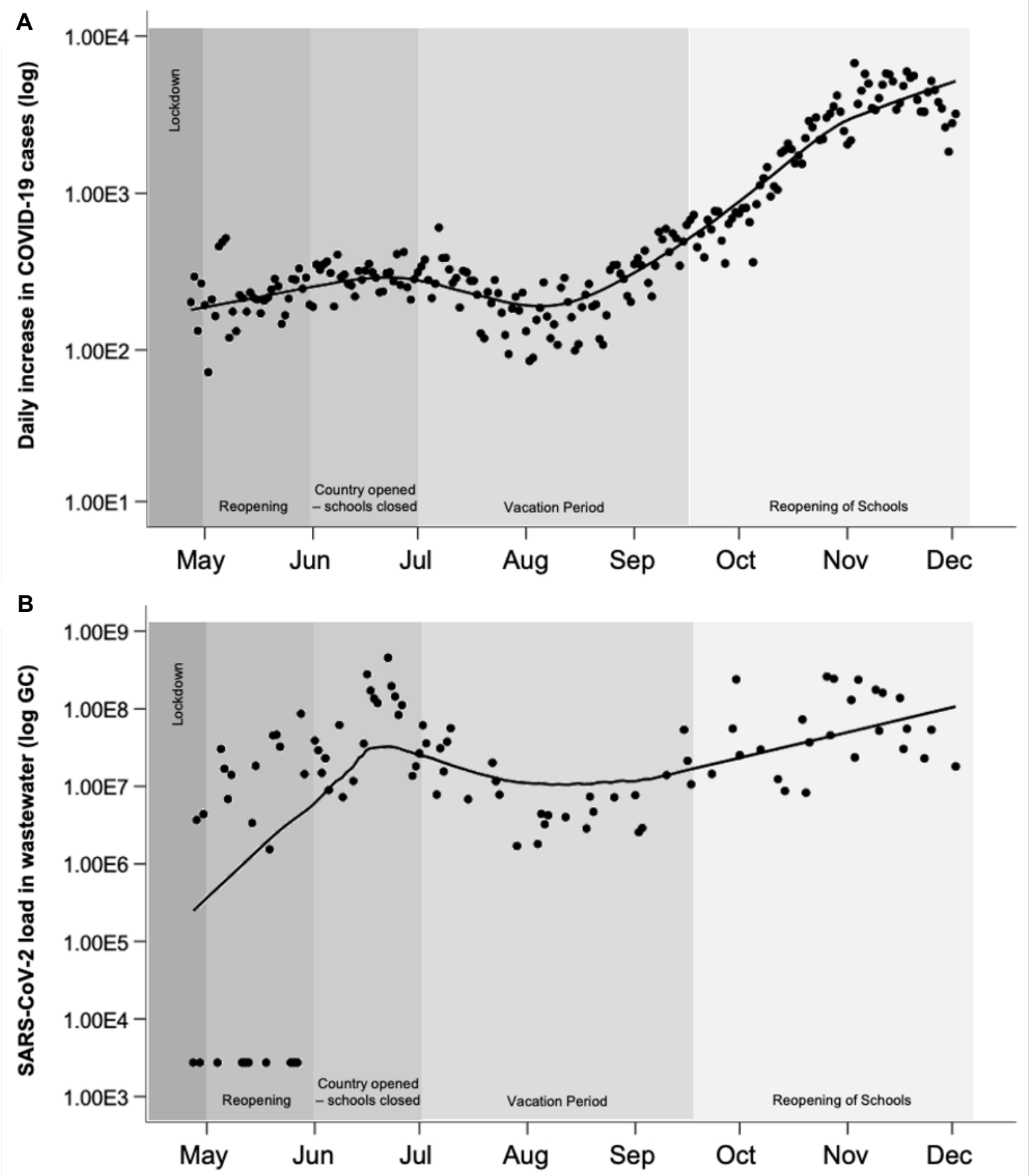

Fig. 5. Daily increase in COVID-19 cases (A) (DGS, 2020) and combined SARS-CoV-2 concentration in 